DOI 10.37882/2223-2982.2021.06-2.22

\title{
НЕКОТОРЫЕ АСПЕКТЫ КОМПЕТЕНТНОСТНОГО ПОДХОДА В ОБУЧЕНИИ СТУДЕНТОВ-ПИАНИСТОВ КОНЦЕРТМЕЙСТЕРСКОМУ МАСТЕРСТВУ
}

\section{SOME ASPECTS OF THE COMPETENCE- BASED APPROACH IN TEACHING PIANISTS TO ACCOMPANIMENT MASTERY \\ I. Pokrovskaya}

Summary: The competence-based approach in the system of teaching professional training of piano students to accompanist mastery is presented as a system of musical and pedagogical methods, scientific approaches, and principles focused on the specifics of individual training, based on federal state standards (FSESRF). Its main task in the educational process is to create a model for the upbringing of an "ideal specialist" in the field of many areas of professional activity of an accompanist. The formation of the need for constant creative self-development of students-pianists becomes the key to the manifestation of competitively capable professional and personal qualities when applying the acquired skills, knowledge, and abilities in the field of accompanist mastery in practice. A systematic approach in this direction is formed on the basis of the personal, cognitive, musical-activity, social-communicative aspects of the formation of professional skills.

Keywords: competence-based approach, accompanist mastery, learning to play in an ensemble, musical and pedagogical education, professional training of accompanists, artistic content of a musical work.

\author{
Покровская Илона Александровна \\ Кониертмейстер, Петрозаводская государственная \\ консерватория имени А.К. Глазунова; соискатель, \\ ГОУ ВО ЛНР «Луганский государственный \\ педагогический университет» \\ pokrova.24.77@yandex.ru
}

Аннотация: Компетентностный подход в системе обучения профессиональной подготовки студентов-пианистов концертмейстерскому мастерству представляется как система музыкально-педагогических методов, научных подходов, и принципов, сориентированных на специфику индивидуального обучения, основанная на федеральных государственных стандартах (ФГОС РФ). Его основной задачей в образовательном процессе становится создание модели воспитания «идеального специалиста» в области многих направлений профессионального деятельности концертмейстера. Формирование потребности постоянного творческого саморазвития студентов-пианистов становится залогом проявления конкурентно способных профессиональных и личностных качеств при применении полученных навыков, знаний, умений в области концертмейстерского мастерства на практике. Системный подход В данном направлении формируется на основе личностного, когнитивного, музыкально-деятельностного, социально-коммуникативного аспектов формирования профессионального мастерства.

Ключевые слова: компетентностный подход, концертмейстерское мастерство, обучение игре в ансамбле, музыкально-педагогическое образование, профессиональная подготовка концертмейстеров, художественное содержание музыкального произведения.

которые обуславливают ее способность решать профессиональные проблемы и задачи с использованием профессионального и жизненного опыта, знаний, творческих умений, творческой активности и самостоятельности для адекватной оценки, «присвоения» и приумножения культурных ценностей» [4, с. 224].

По мнению Е.Р. Сизовой изучение социально-культурных условий деятельности музыканта показывает, что специалист любого профиля подготовки должен обладать рядом профессиональных и личностных качеств, которые отражают общественный эталон выпускника музыкального учебного заведения и формируют «модель идеального специалиста» [5].

Наиболее важными среди них являются: мотивация профессиональной музыкальной деятельности, ценностное отношение к профессии; профессиональное исполнительское мастерство, опыт творческой деятельности; фундаментальная общетеоретическая, психолого-педагогическая и специальная музыкальная 
подготовка; развитая коммуникативная сфера; индивидуально-психологические качества личности, позволяющие самосовершенствоваться в профессии [1], [2], [3], [6], [7]. Социальный заказ формирует «модель идеального специалиста», главным фактором которого выступает профессиональная компетентность.

В контексте обучения студентов-пианистов концертмейстерскому мастерству заметим, что постижение гармонической и полифонической фактуры фортепианных произведений разных эпох обогащает их профессиональный опыт, способствует поиску связи звучания и смысла, бережному отношению к тексту в процессе интонирования, которое на рояле значительно отличается от других инструментах в силу его затухания. Эта особенность способствует развитию тонкости восприятия, музыкального слуха, побуждая студента овладевать приемами игры legato на фортепиано, приемами извлечения тембрового окраса звука, выразительной фразировки.

Развитию мышления и памяти способствует исполнение фортепианных произведений наизусть, а умению анализировать их фактуру - гармонический, полифонический и мелодический слух, когда требуется вычленение в ней смысловых элементов формы: повторов, кульминаций, контрастов и т.п. Способности добиваться поставленных целей для овладения принципами и приемами игры на фортепиано, способствует усидчивость и воспитание волевых качеств, что в целом формирует оценочные представления о будущей профессии.

Бесспорно, компетентностный подход детерминирует необходимость постоянного творческого саморазвития студентов-пианистов, обеспечивая формирование профессиональных и личностных качеств в успешном применении полученных навыков, знаний, умений в области концертмейстерского мастерства.

Например, в основной профессиональной образовательной программе Петрозаводской государственной консерватории имени А.К. Глазунова «Концертмейстерский класс» по направлению подготовки 53.05.01 «Искусство концертного исполнительства (специализация Фортепиано)» студенты-пианисты должны:

знать:

- основные типы форм классической и современной музыки; тембровые и технологические возможности исторических и современных музыкальных инструментов; основные направления и стили музыки XX - начала XXI вв.;

- конструктивные и звуковые особенности инструмента; различные виды нотации, исполнительские средства выразительности;

- концертно-исполнительский репертуар, включающий произведения разных эпох, стилей, жанров; основные элементы музыкального языка в целях грамотного и свободного прочтения нотного текста;

- методы и способы работы над художественным образом музыкального произведения; основы исполнительской интерпретации;

- историю, теорию и практику ансамблевого исполнительства; принципы работы над музыкальным произведением в ансамбле и особенности репетиционного процесса;

- особенности исполнительской стилистики от эпохи барокко до современности, основы исполнительской интерпретации, композиторские стили;

- основы строения музыкальных произведений различных эпох, стилей, жанров; основные этапы создания музыкально-исполнительской концепции;

- концертный, ансамблевый репертуар, включающий произведения разных эпох, стилей, жанров; основные принципы совместного исполнительства; возможности и варианты организации мероприятий, базовые принципы построения публичного выступления и поведения на сцене, в том числе взаимоотношения в творческом процессе «композитор - исполнитель - слушатель».

уметь:

- применять полученные теоретические и исторические знания в последующей профессиональной деятельности; самостоятельно работать с различными типами нотации; озвучивать на инструменте и (или) голосом (в работе над вокальными сочинениями) нотный текст различных эпох и стилей;

- передавать в процессе исполнения композиционные и стилистические особенности сочинения; использовать многочисленные, в том числе тембральные и динамические, возможности инструмента;

- анализировать художественные и технические особенности музыкальных произведений; распознавать различные типы нотаций;

- поддерживать свой игровой аппарат в хорошей технической форме.

- сохранять в ансамбле единое ощущение музыкального времени и агогики;

- слышать свою партию и партии партнеров по ансамблю; соблюдать динамический баланс с участниками ансамбля;

- ориентироваться в композиторских стилях, жанрах и формах в историческом аспекте, находить индивидуальные пути воплощения музыкальных образов в соответствии со стилем композитора;

- раскрывать художественное содержание музыкального произведения; формировать исполнительский план музыкального сочинения; 
- самостоятельно преодолевать технические и художественные трудности в исполняемом произведении; взаимодействовать с другими музыкантами в различных творческих ситуациях;

- рассматривать музыкальное произведение в динамике исторического, художественного и социально-культурного процессов; осуществлять на высоком уровне музыкально-просветительскую (лекторскую и/или исполнительскую) деятельность.

владеть:

- навыками работы с учебно-методической, справочной и научной литературой, аудио- и видеоматериалами, интернет-ресурсами по проблематике дисциплины «концертмейстерский класс»;

- профессиональной терминологией, включая музыкальные термины на итальянском (как минимум), немецком, французском языках; различными видами нотации;

- навыками чтения различных видов нотного текста, предназначенных для исполнения на инструменте; навыками самостоятельной работы на инструменте;

- навыками чтения с листа партий различной сложности и транспонирования партий меньшей трудности; искусством выразительного интонирования, разнообразными приемами звукоизвлечения, артикуляции, фразировки;

- способностью к сотворчеству при исполнении музыкального произведения в ансамбле; навыками концертного исполнения музыкальных произведений, как в качестве солиста, так и в составе ансамбля;

- навыками самостоятельной работы на инструменте над ансамблевыми произведениями различных стилей и жанров; искусством игры в ансамбле;

- навыками воплощения художественного образа произведения в соответствии с особенностями композиторского стиля; навыками самостоятельного анализа художественных и технических особенностей музыкального произведения;

- музыкально-исполнительскими средствами выразительности; навыками создания собственной интерпретации музыкального произведения; навыками работы в составе ансамбля, творческого коллектива;

- навыками самостоятельной работы над концертным, ансамблевым, сольным репертуаром; навыками работы в составе ансамбля, творческого коллектива.

- навыками критического мышления; основами пропаганды достижений музыкального искусства.

Очевидно, что данные формулировки отражают компетентностный подход в формировании личностных качеств студентов-пианистов для будущей профессио- нальной деятельности в качестве концертмейстера.

В данном контексте Е.Р. Сизова определяет понятие «музыкальная компетентность», как определённую структуру, в которой интегрируются личностный, когнитивный, музыкально-деятельностный, социально-коммуникативный аспекты профессионального мастерства. [5, с. 22]. По её мнению, личностный аспект включает индивидуальные характеристики музыканта, отражающие степень развития его ценностных ориентаций, мотивационной, эмоционально-волевой, перцептивно-рефлексивной сферы, музыкальных способностей. Когнитивный аспект фиксирует систему гуманитарных, музыкально-теоретических, психолого-педагогических, специальных музыкальных знаний, необходимых для осуществления всех видов профессиональной деятельности. Музыкально-деятельностный аспект обобщает комплекс умений и навыков, необходимых музыканту в перцептивной, аналитической, исполнительской и педагогической деятельности, обеспечивает эффективное протекание процессов восприятия, изучения, исполнения музыки. Социально-коммуникативный аспект определяет комплекс умений и навыков, необходимых для усвоения и передачи музыкальной информации, осуществления информационного обмена и межличностного взаимодействия в педагогическом и творческом процессе.

Исходя из выше сказанного, отметим, что результативность и успех в любой сфере человеческой деятельности в значительной мере зависят от ее общественной значимости. К сожалению, в настоящее время мы можем говорить о потере престижа фортепианной подготовки в системе музыкального образования. Анализ причин подобного положения позволяет выделить ряд факторов объективного и субъективного характера, негативно влияющих на данный процесс.

Обострение демографической ситуации в стране стало объективным фактором уменьшения абитуриентов, что обусловило отсутствие конкурсов при поступлении в музыкальные вузы, лишив возможности отбора музыкально одаренной молодежи. В то же время, современные социально-экономические особенности нередко заставляют руководителей учебных заведений привлекать обучающийся контингент престижными, востребованными, привлекательными специальностями, что приводит к потере приоритетных позиций фортепианного искусства, ориентированного, прежде всего, на духовное становление личности.

Обострение противоречий между требованиями общества к выпускникам по направлению подготовки 53.03.02 «Музыкальное образование» (профиль «Фортепиано»), по специальности 53.05.01 «Искусство концертного исполнительства» и профессиональным уровнем студентов-пианистов обусловливает потребность в ор- 
ганизации профессиональной подготовки обучающихся на основе системного подхода. Охватывая различные аспекты содержания и процесса профессиональной подготовки студентов-пианистов, системный подход позволяет обеспечить действенность важнейших принципов, составляющих основу фортепианного обучения: увеличение и обогащение исполнительского репертуара; ускорение темпов изучения и обновления учебного материала; обеспечение интеллектуализации процесса обучения, увеличение диапазона музыкально-теоретических знаний; активизация самостоятельности, творческой инициативы обучающихся.

По мнению А.И. Щербаковой [8], системный подход применим во всех видах учебного процесса: в рамках индивидуальных занятий, в лекционной и семинарской работе, на базе исполнительской практики студентов. В лекционных курсах студенты получают представление о системном стиле мышления, необходимом для постижения мира музыки в системной целостности, учатся определять свое место в этом мире, формировать собственные ценностные приоритеты и цели будущей профессиональной деятельности.

На семинарских занятиях с помощью системного подхода подвергаются сравнительному анализу проблемы освоения музыки разных эпох, осваивается техника жанрово-стилевых, интонационно-стилевых и ассоциативных аналогий, выявляются особенности каждого авторского мира в его соотнесенности с социокультурным фоном его времени и сегодняшним днем.

В данном случае, А.И. Щербакова характеризует системный подход как обобщающую направленность в процессе профессиональной подготовки студентовпианистов, а именно: сформулировать концепцию постоянно развивающегося музыкального пространства как проявления саморазвивающейся сущности музыки; осознать формирование ценностных ориентаций в музыкально-педагогическом образовании как процесс ценностного становления личности; поставить задачи, направленные на решение проблем музыкальной герменевтики (понимания и толкования музыкального текста), через осмысление взаимозависимости музыкального языка и музыкального мышления различных исторических эпох; осознать взаимосвязь между воспитанием гармоничной творческой личности и целостным постижением музыкального пространства; сформулировать принципы формирования исполнительского и музыкально-педагогического репертуара, адекватные современным тенденциям развития музыкального искусства [8].

В результате, компетентностный подход интегрирует различные аспекты профессионального мастерства, способствуя формированию системы ценностных ориентаций и создавая концептуальные модели в будущей деятельности студента-пианиста в качестве концертмейстера, подготавливая его, таким образом, к профессиональной самооценке и творческому поиску при неизменном присутствии самоконтроля. Являясь системой музыкально-педагогических методов, научных подходов, и принципов, сориентированных на специфику индивидуального обучения, процесс профессиональной подготовки студентов-пианистов нуждается в постоянном обновлении, переосмыслении, поиске новых путей совершенствования в обучении концертмейстерскому мастерству.

\section{ЛИТЕРАТУРА}

1. Адам, С. Результаты обучения: состояние дел в Европе. Новое в применении результатов обучения в контексте болонского процесса / С. Адам // Болонский процесс : Результаты обучения и компетентностный подход (книга-приложение 1). - М., 2009. -325 с.

2. Байденко, В.И. Новые стандарты высшего образования: методологические аспекты / В.И. Байденко // Высшее образование сегодня. - М., 2007. № 5. - С. 4-9.

3. Зеленкова, Е.В. Компетентностный подход в профессиональной подготовке музыканта-педагога / Е.В. Зеленкова // Особенности применения теоретического знания в преподавании гуманитарных дисциплин в музыкальном учебном заведении: матер. Всеросс. науч.-практ. конф. - М., 2008. - С. 13-18

4. Радынова 0.П., Печерская А.Б., Хазанов П.А. Развитие профессиональной культуры студентов музыкальных вузов на занятиях фортепиано: компетентностный подход // Преподаватель XXI век. - 2016. - № 2. --231 с.

5. Сизова Е.Р. Профессиональная подготовка специалистов в системе классического музыкального образования: автореферат дис. ... доктора педагогических наук : 13.00.08 / Сизова Елена Равильевна; [Место защиты: Акад. повышения квалификации и проф. переподгот. работников образования]. Москва, 2008. -43 c.

6. Стандарты образования ЛНР [Электронный ресурс]. - Режим доступа : https://minobr.su/educations-standarts.html. - Загл. с экрана. - Дата обращения: 12.02.17.

7. Федеральный государственный образовательный стандарт высшего образования по специальности 53.05 .01 Искусство концертного исполнительства (уровень специалитета) [Электронный ресурс]. - Режим доступа: http://fgosvo.ru/news/7/2023 (Дата обращения 22.12.2020).

8. Щербакова А.И. Системный подход в определении путей совершенствовании современной системы музыкального образования / А.И. Щербакова // Философия современного образования. - М., 2011. - С.30-35.

(с) Покровская Илона Александровна (pokrova.24.77@yandex.ru).

Журнал «Современная наука: актуальные проблемы теории и практики» 